Proc. Estonian Acad. Sci. Eng., 2006, 12, 4, 435-444

\title{
Characterization of WC-Co composite thermal spray powders and coatings
}

\author{
Priidu Peetsalu ${ }^{\mathrm{a}}$, Sergei Zimakov ${ }^{\mathrm{a}}$, Jüri Pirso ${ }^{\mathrm{a}}$, Valdek Mikli $^{\mathrm{b}}$, Riho Tarbe $^{\mathrm{a}}$ \\ and Priit Kulu ${ }^{\mathrm{a}}$ \\ a Department of Materials Engineering, Tallinn University of Technology, Ehitajate tee 5, 19086 \\ Tallinn, Estonia; priidup@ttu.ee \\ b Centre for Materials Research, Tallinn University of Technology, Ehitajate tee 5, 19086 Tallinn, \\ Estonia; miku@ttu.ee
}

Received 2 June 2006, in revised form 7 November 2006

\begin{abstract}
The article studies methods for describing powder granules and coatings in WC-Co thermal spray powder development and production. Powder particles and microstructure grains vary from a few nanometres to hundreds of micrometres. It is therefore necessary to combine different methods of analysis. In the granule and particle size analysis, laser diffraction, sieve analysis, image analysis and the BET method are used. Both the macrostructure and microstructure of the thermal spray coating and composite powder granules are investigated including computer analysis. As a result, a numerical database was obtained that permits to compare the characteristics of different coatings and to analyse the resistance of the coatings to the abrasive wear.
\end{abstract}

Key words: powder granule, coating, microstructure, abrasive wear.

\section{INTRODUCTION}

Thermal spray coatings have a wide range of applications, for instance, by repairing machine parts damaged in service or by the production of parts with high wear resistance. The wear resistance of a coating does not depend only on the spray system used, but also on the characteristics of the particular spray powder.

Previous studies have demonstrated $\left[^{1,2}\right]$ that the use of recycled hardmetal powders in the formation of detonation coatings leads to numerous problems. Hardmetal powder particles sized from 32 to $40 \mu \mathrm{m}$ in a detonation spray produce very porous (4 to 5\%) non-uniform coatings. Therefore, a new technology - mechanically activated synthesis $\left[{ }^{3}\right]$ - was used to produce experi- 
mental WC-based composite spray powders. The new experimental powder increases the wear resistance of the coating $\left[{ }^{4}\right]$.

To guarantee high abrasive wear resistance of a coating, it is necessary to optimize the structure of the coating. Microstructure analysis gives combined characterization of the morphology, elemental composition and crystallography of the coating $\left[{ }^{5}\right]$. Studies of the composite powder granule structure $\left[{ }^{4}\right]$ show that no single universal method exists to acquire all the information needed for the material structure characterization. Thus the choice of the method depends on the researcher. However, sometimes the chosen methods do not provide reliable information because of insufficient experience. Inaccurate results typically occur, when computer-aided measurements are relied on with no reservations. In fact, computer-aided microstructural analysis can provide highly accurate information in a short time.

The article focuses on the analysis of the structure of the coating and the use of the obtained data with the aim to improve abrasive wear resistance of the coating.

\section{EXPERIMENTAL}

\subsection{Materials}

Tungsten carbide-cobalt based hardmetal powders were used as coating materials. The HVOF spraying system TAFA JP 5000 (Praxair Tafa, USA) with kerosene as fuel was used for the deposition of the coating. Table 1 lists the coatings and their indexing system.

\subsection{Characterization of the granularity and chemical composition of the composite powder}

Granule size and distribution in the investigated powders were examined with three methods:

- sieve analysis,

- laser diffraction analysis by Laser Particle Sizer "Analysette 22" Compact,

- image analysis based on the Image-Pro Plus 3.0 system and the corresponding data processing programs.

Table 1. Investigated coatings, spray powders, and the indexing system

\begin{tabular}{c|c|c}
\hline $\begin{array}{c}\text { Coating } \\
\text { index }\end{array}$ & \multicolumn{1}{|c|}{ Type of the coating } & $\begin{array}{c}\text { Powder particle size, } \\
\mu \mathrm{m}\end{array}$ \\
\hline No. 2 & (WC-Co)-15Co (experimental, agglomerated) & $15-45$ \\
No. 4 & WC-17Co (TAFA 1343 V, commercial) & $20-50$ \\
No. 5 & WC-15Co (mechanically activated synthesis) & $20-45$
\end{tabular}


The chemical composition of powder particles was studied by means of the energy dispersive X-ray microanalysis (EDS) in the Link Analytical AN10000 system. X-ray mapping technique was used to evaluate element distribution inside powder particles. According to the results, the resolution of element distribution is from 0.5 to $1 \mu \mathrm{m}$. Carbon and oxygen content in the spray powder were measured by the element analysis system Vario EL V2.6 (Elementar Analysen - systeme $\mathrm{GmbH}$ ).

\subsection{Characterization of the microstructure of coatings and powder granules}

To analyse the structure of the particles and coatings, cross-section polishes were made by a mechanical grinding-polishing procedure. To analyse the structure and composition of a coating, cross-section polishes were made by hot mounting. The best results for the powder were obtained with a fluid (not viscous) cold mounting with an epoxy-based compound that was mounted by help of the Buehler vacuum impregnation system. The cross-section polishes of the coating were made by hot mounting. Due to the high hardness of WCparticles, diamond grinding-polishing was used.

The microstructure of the powder granules and the coating was investigated by means of the optical microscope Axiovert 25 and scanning electron microscope (SEM) Jeol JSM-840A using backscattered electron imaging. Quantitative results of the structure analysis were obtained by the image analysis systems Buehler Omnimet Image Analysis System Version 5.40 (OM) and Image Pro 3.0.

To describe the microstructure of the grains and the shape of the powder granules, the following parameters were used: roughness is defined as the ratio of the convex perimeter to the perimeter (if there are no concave parts at the perimeter of the particle, the roughness of the particle is 1.0); sphericity is defined as $4 \pi \times$ area/(perimeter squared) (if the shape of the particle is a perfect circle, the sphericity of the particle is 1); aspect ratio refers to the longest axis of the observed object, divided by the shortest axis of the latter $\left[{ }^{6}\right]$.

The phase composition study of investigated samples was carried out on a Bruker D5005 X-ray diffractometer (XRD), using $\mathrm{Cu} \mathrm{K}_{\mathrm{a}}$ radiation at $40 \mathrm{kV}$ and $40 \mathrm{~mA}$. The range was 11 to $70^{\circ}$ by step $0.040^{\circ}$ and step time was $3 \mathrm{~s}$.

\section{RESULTS}

\subsection{Size and morphology of WC-Co based composite spray powder granules}

To produce composite powders with sub-micrometric WC grains, it is necessary to analyse a sub-micrometric powder. Indirect methods like BET or XRD can be used to measure the WC powder (from 20 to $500 \mathrm{~nm}$ ). The BET method enables us to find the size of the surface area and then calculate the average particle size. The 
XRD method provides a picture of distribution (not precise, though) and an average value of the crystal size. In the case of nano-size powders, the grain and the crystal are usually of the same size. When treating nano-size particles, care should be taken not to oxidize particles during measurements.

For thermal spray, the granule size of the powder should range from 20 to $45 \mu \mathrm{m}$ to achieve high productivity of spraying and to avoid oxidation processes $\left.{ }^{7}\right]$. It is much easier to determine the size and size distribution of composite powder granules because of their larger size. For these purposes, range, sieve and laser particle size analysis can be used.

Sieve and laser analysis may yield different results because of the elongation of the granules (Fig. 1b). To characterize their elongation, the aspect ratio AS $\left[{ }^{6}\right]$ was used. The mean aspect ratio was 1.96 , which means that the longest diagonal of the particle is almost twice as long as the smallest one. Because of such elongation, the granule size, measured by a laser diffraction analyser, was larger than $45 \mu \mathrm{m}$ (the largest by sieving). By the laser analysis, $28 \%$ of the granules measured over $50 \mu \mathrm{m}$ and $5 \%$ less than $20 \mu \mathrm{m}$ (smallest by sieving). Granules over $45 \mu \mathrm{m}$ can go through the sieve because of their elongated shape $\left.{ }^{8}\right]$. Granule size distribution is shown in Fig. 2.

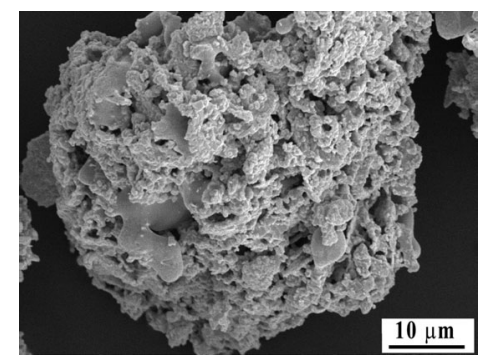

(a)

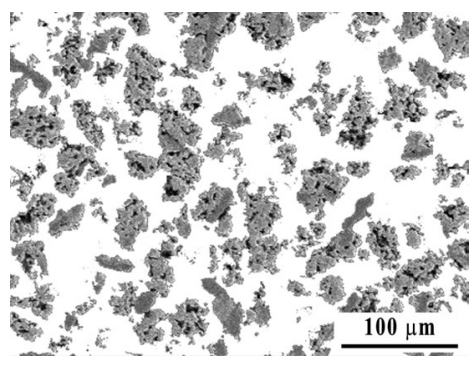

(b)

Fig. 1. SEM micrographs of the powder No. 5: (a) granule; (b) cross-section of the granules.

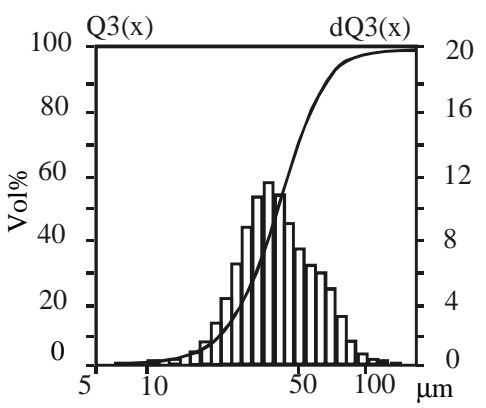

(a)

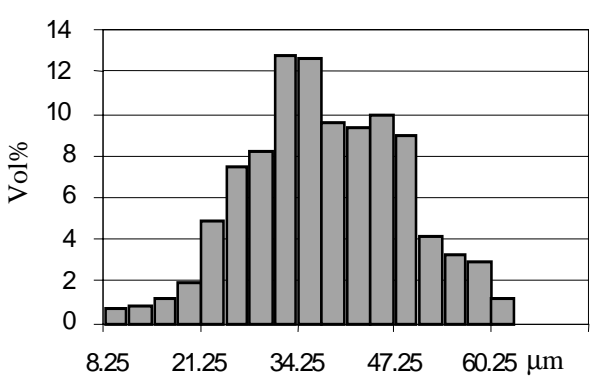

(b)

Fig. 2. Volume distribution of the powder No. 5 granules: (a) measured by laser particle analyser; (b) obtained by image analysis. 
The results of image analysis for the granule size using the IP system were similar to those of the laser analysis (Fig. 2). For the image analysis, it is necessary to prepare powder cross-section polishes and pictures. On pictures of the image analysis, granules have to be cleaned and separated from each other (Fig. 1b), therefore it is easier to perform laser and sieve analysis. The pictures can be used for verifying the results, especially in cases where the results are somewhat incorrect.

Indirect methods are not suitable for the analysis of granule sizes of composite powders. The BET analyses indicated a larger surface area because of open porosity (Fig. 1a). XRD can provide the size of WC crystals.

\subsection{Composition and phase analysis of WC-Co based composite spray powders and coatings}

Chemical composition analysis of the WC-Co powder is complicated. To obtain accurate results, it is necessary to combine EDS (W and Co) and elemental analysis $(\mathrm{O}$ and $\mathrm{C})$. To understand the relation between the elements, phase analysis can be used. The most effective and easiest way to analyse powder phases is the XRD analysis. WC-Co granules and coatings mainly have two phases (WC and pure Co), and the phase composition can be studied with XRD, SEM and X-ray mapping. According to the XRD analysis, powder granules have the following additional phases: $\mathrm{W}$ and $\mathrm{Co}_{3} \mathrm{~W}_{3} \mathrm{C}$. The coating has the same phases, except that $\mathrm{CoO}$ appeared as a result of oxidation during the spraying process (Fig. 3). The XRD analysis does not show the Co phase because the XRD is not sensitive to cobalt $\left[{ }^{9}\right]$. SEM photographs, X-ray mapping and hardness testing confirm that pure Co is one phase (Fig. $4 \mathrm{c}$ ). $\mathrm{Co}_{3} \mathrm{~W}_{3} \mathrm{C}$ is formed because of the low carbon content $(4 \%)$ in the powder $\left[{ }^{10}\right]$.

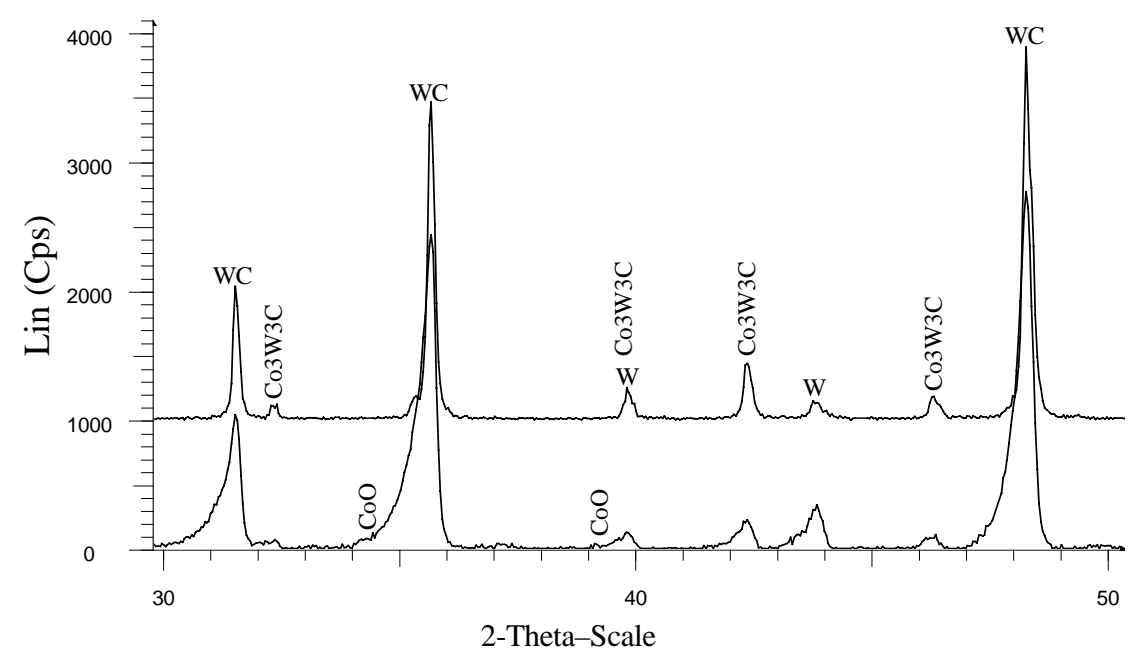

Fig. 3. XRD phase analysis of a composite powder and coating. 


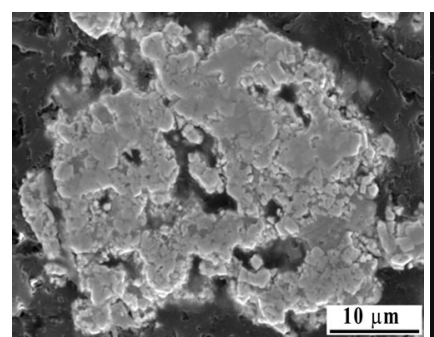

(a)

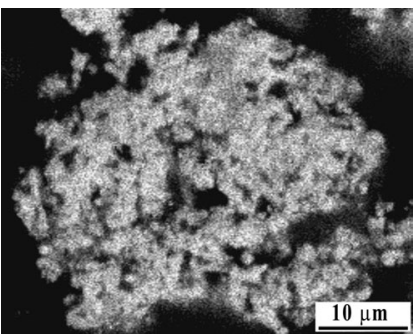

(b)

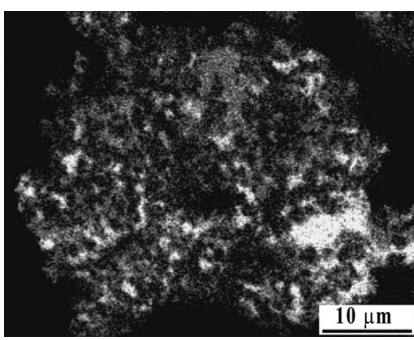

(c)

Fig. 4. WC-Co composite particle examined by X-ray mapping: (a) SEM photo; (b) distribution of $\mathrm{W}$; (c) distribution of Co.

The X-ray mapping pictures of $\mathrm{W}$ and Co, and the SEM picture (Fig. 4) confirm our understanding of the SEM image picture phase tones (W and Co have different tones under SEM because their atoms have different masses). But the mapping picture resolution (from 0.5 to $1 \mu \mathrm{m}$ ) and quality are not as good as in the SEM image for image analysis. Therefore, SEM photos can provide more information for the exact phase analysis.

\subsection{Characterization of composite powder granules and of the coating microstructure}

Micro- and sub-microstructure can be of key importance when good abrasive wear resistance is to be achieved. In order to obtain comparable information on the microstructure and porosity, the same methods must be used. There exist several methods for describing the structure. However, even using the same methods, the values can differ, and even the results of a computerized analysis depend on the researcher. Therefore, the structure and porosity analysis requires a good statistical database. The database cannot consist only of pictures of the same area, the area investigated should be large. In most cases, the area of a sample is rather limited and therefore studies are based on one area. However, this does not mean that the test area has the same structure. Figure 5 shows the

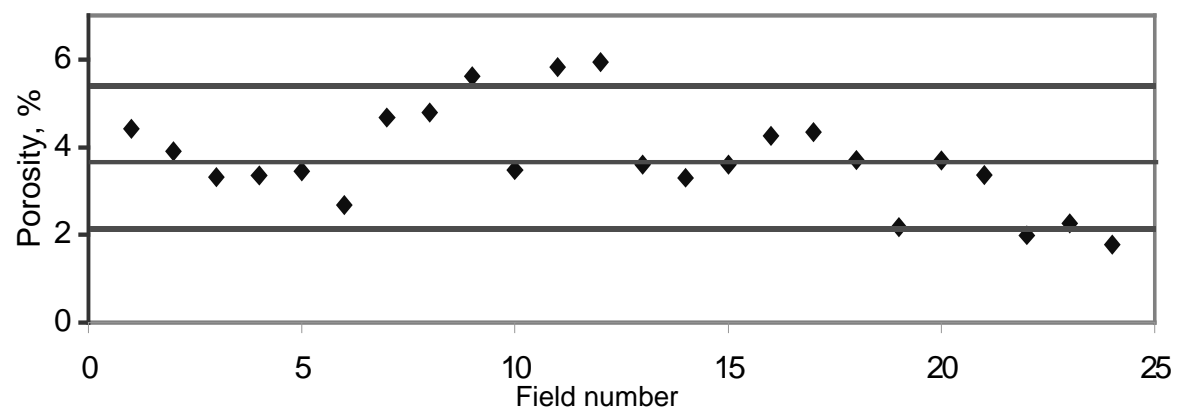

Fig. 5. Porosity of the coating No. 2 in different fields. 
results of the porosity analysis in different fields (polished surface and light microscope pictures with the magnification $\times 500$ ). In porosity measurements, the type of the microscope used is important. The porosity, obtained from SEM pictures, is much higher than that in the pictures obtained by means of an optical microscope. The results taken from pictures with $\times 2000($ SEM) and $\times 500$ (optical microscope) are shown in Table 2.

There is a specific ratio in the porosity: microporosity is twice as high as macroporosity. Probably the optical microscope did not detect microporosity and SEM showed black phases that consist of lighter elements. The results of the optical microscope are more reliable than those based on the SEM pictures.

The microstructure and porosity of composite powder granules and coatings were analysed by OM and IP systems based on the computer-corrected pictures, where only some corrections were made manually. The results are shown in Tables 2 and 3.

Table 3 shows no direct dependence of the wear resistance on the microstructure. The main characteristics of the microstructure (WC-Co) that have an effect on the abrasive wear resistance of the coating are porosity, grain size and size distribution $\left[{ }^{11}\right]$. Therefore particle size distribution by their volume is a better indicator, showing differences between the microstructures (Fig. 6) $\left[{ }^{12}\right]$. Other grain size distributions and mean sizes have very low influence as all coatings have almost the same spherical mean diameter (Table 3). Particle size distribution function by volume is shown in Fig. 7 and mean diameters are shown in Table 3.

Table 2. Phase areas and relative wear resistance

\begin{tabular}{lccc}
\hline \multicolumn{1}{c|}{ Parameters } & No. 2 & No. 4 & No. 5 \\
\hline Hard phase, \% & 38.2 & 48.5 & 44.4 \\
Matrix, \% & 42.5 & 49.2 & 51.9 \\
Porosity, \% (SEM) micro & 19.2 & 2.4 & 3.8 \\
Porosity, \% (optical microscope) macro & 3.7 & 0.13 & 0.59 \\
Relative wear resistance & 5.3 & 10.3 & 23.2
\end{tabular}

Table 3. Results of structural analysis with OM

\begin{tabular}{lcc|c}
\hline \multicolumn{1}{c|}{ Parameters } & No. 2 & No. 4 & No. 5 \\
\hline Volume count mean diameter, $\mu \mathrm{m}$ & 1.2 & 1.8 & 1.1 \\
Spherical mean diameter, $\mu \mathrm{m}$ & 0.7 & 0.8 & 0.8 \\
Roughness & 0.9 & 0.9 & 0.9 \\
Sphericity & 0.6 & 0.6 & 0.6
\end{tabular}




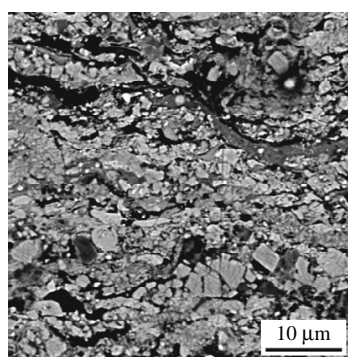

(a)

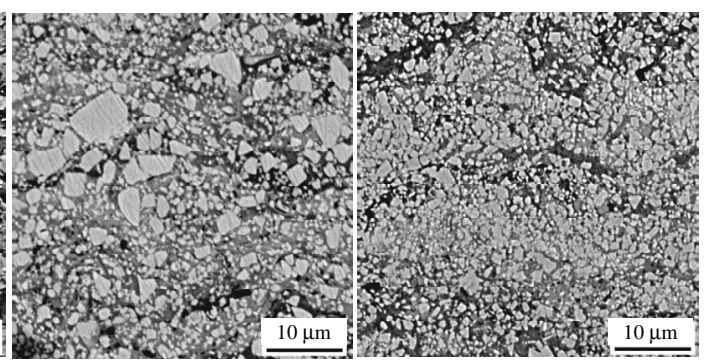

(b) (c)

Fig. 6. SEM pictures of the microstructure of the coatings: (a) specimen No. 2; (b) No. 4; (c) No. 5.

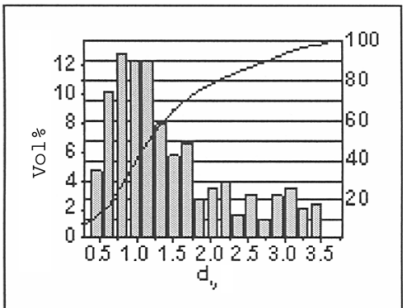

(a)

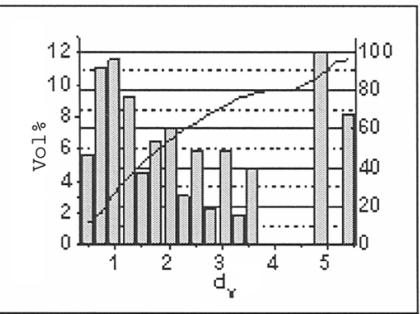

(b)

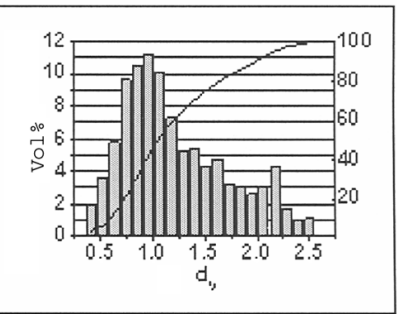

(c)

Fig. 7. Grain size distribution by particle volume of the hardmetal: (a) specimen No. 2; (b) No. 4; (c) No. 5 .

Differences in volume distributions are clearly visible. Coating No. 5 has high wear resistance because of small and homogeneously distributed grains. In WC grain size distribution, the main mode is at $0.9 \mu \mathrm{m}$ and the other at $2.2 \mu \mathrm{m}$. Despite the smaller porosity of coating No. 4 (as compared to No. 5), wear resistance is not so good because the average size of larger particles is $5 \mu \mathrm{m}$, although the average size of small grains is the same $-0.9 \mu \mathrm{m}$. It means that in coating No. 5 grain size differences between large and small particles are smaller. The structure of the coating No. 2 has approximately the same distribution of small and larger particles as No. 5 but its porosity is six times higher (in specimen No. 2 for $3.7 \%$ and in specimen No. 5 for $0.59 \%$ ) and therefore wear resistance is low.

Based on the experiments and microstructural analysis, dry abrasive wear resistance of the WC-Co coatings depends mainly on porosity, carbide content in the coating and volume size distribution. Other investigated parameters have minor effect on wear resistance. 


\section{CONCLUSIONS}

1. To characterize the microstructure and sub-microstructure of thermal spray composite powder granules and coatings, numerical values are needed for comparison with other experimental results.

2. To obtain average numerical values of the microstructure and porosity, it is necessary to examine more fields (from 15 to 20 fields depending on the homogeneity of the structure of the coating).

3. Counted grain size distribution of the particle size is not sensitive to changes in the microstructure; therefore, in order to obtain useful information, grain size distribution by volume must be used.

4. Microstructural analysis of coatings enables us to show that for a particular WC particle volume distribution, uniform distribution of small-size hard particles (about $1 \mu \mathrm{m}$ ) and a certain amount (5 to $10 \mathrm{vol} \%$ ) of larger hard particles (from 2 to $3 \mu \mathrm{m}$ ) is one of the main reasons of good dry abrasive wear resistance.

5. High porosity of a coating (about from 2 to 3\%) can reduce its wear resistance.

\section{ACKNOWLEDGEMENT}

This work was supported by the Estonian Science Foundation (grant No. 5881).

\section{REFERENCES}

1. Kulu, P. and Zimakov, S. Wear resistance of thermal sprayed coatings on the base of recycled hardmetal. Surface Coatings Technol., 2000, 130, 46-51.

2. Kulu, P., Pihl, T. and Zimakov, S. Wear resistance of thermal sprayed coatings. In Proc. International Conference BALTTRIB'99 . Kaunas, 1999, 311-318.

3. Peetsalu, P., Zimakov, S., Pirso, J., Mikli, V., Tarbe, R. and Kulu, P. Technology and characterization of composite thermal spray powders. J. Mater. Sci. (Medziagotyra), 2005, 11, 385-389.

4. Peetsalu, P., Zimakov, S., Pirso, J., Mikli, V., Tarbe, R. and Kulu, P. Characterization of composite thermal spray powders. In Euro PM2005 Congress and Exhibition. Prague, 2005, vol. 2, 87-92.

5. Metals Handbook, 2nd ed. ASM International, Materials Park, Ohio, 1998.

6. Particular Guide to Image Analysis. ASM International, Materials Park, Ohio, 2000.

7. Zimmermann, S., Keller, H. and Schwier, G. New carbide based materials for HVOF spraying. In Thermal Spray 2003: Advancing the Science and Applying the Technology. Orlando, Florida, 2003, 227-232.

8. Mikli, V., Kulu, P. and Käerdi, H. Application of image analysis methods to characterize impact-milled WC-Co powder particles. Image Anal. Stereol., 2001, 20, 199-204.

9. Jenkins, R. and Snyder, L. R. Introduction To X-Ray Powder Diffractometry. J. Wiley, New York, 1996. 
10. Cemented Tungsten Carbides. Production, Properties, and Testing (Upafhyaya, G. S., ed.). Noyes Publ., Westwood, 1998.

11. Roebuck, B. and Gee, M. G. Abrasion resistance of wide grained WC/Co hardmetals: In Proc. European Powder Metallurgy Congress PM 2002. Lausanne, 2002, 129-135.

12. Mikli, V., Kulu, P., Tümanok, A. and Käerdi, H. Comparative investigation of disintegrated WC-Co powders by the methods of sieving and image analysis. In Proc. 7th International Conference "Materials Engineering-98”. Jurmala, 1998, 9-13.

\title{
WC-Co komposiitpihustuspulbrite ja nendest saadud pinnete kirjeldamine
}

\author{
Priidu Peetsalu, Sergei Zimakov, Jüri Pirso, Valdek Mikli, Riho Tarbe \\ ja Priit Kulu
}

On uuritud WC-Co komposiitpulbrite ja nendest saadud pinnete kirjeldamise meetodeid. Eesmärgiks on tagada efektiivne pulbrite kirjeldamine tootmiseks ja arendamiseks. Pulbri ja pinde mikrostruktuuri osakesed varieeruvad mõnest nanomeetrist kuni saja mikromeetrini, mistõttu ei ole olemas ühtki universaalset meetodit nende suuruse, kuju ja keemilise koostise määramiseks. Graanulite suurus on vahemikus mõnest mikromeetrist kuni saja mikromeetrini, mistõttu saab nende uurimiseks efektiivselt rakendada laser- ning sõelanalüüsi ja kontrolliks kujutisanalüüsi. Graanulite valmistamiseks kasutatavate nanomeetriliste pulbrite osakeste suuruse mõõtmiseks kasutatakse kaudseid meetodeid (BET-meetod osakeste eripinna ja XRD-meetod kristallilisuse määramiseks), mida ei saa rakendada graanulite suuruse mõõtmiseks. Graanulite ja pinde struktuuri uuringud on läbi viidud kahel suurendusel, millest väiksemat kasutatakse poorsuse määramiseks optilise mikroskoobiga ja suuremat SEM-i abil mikrostruktuuris oleva WC osakeste suuruse ja nende jaotuse analüüsiks. Piltide analüüsiks on kasutatud arvutianalüüsi. Viimase teostamisel on uuritud vigade võimalusi ja on toodud poorsuse määramisel erinevatel väljadel saadud tulemused. Lõpptulemusena on leitud, et pinde abrasiivkulumine sõltub eelkõige WC osakeste suurusest, jaotusest ja pinde poorsusest. 